\title{
Sources and bibliography
}

\section{Primary sources}

\section{Denkschrift}

Denkschrift über die Aufstellung eines deutschen Kontingents im Rahmen einer internationalen Streitmacht zur Verteidigung West-Europas (Himmeroder Denkschrift)

\section{Defence (BMVg) White Papers}

Weissbuch 1970, 'Zur Sicherheit der Bundesrepublik Deutschland und zur Entwicklung der Bundeswehr', Bonn, May

Weissbuch 1971-72, 'Zur Sicherheit der Bundesrepublik Deutschland und zur Entwicklung der Bundeswehr', Bonn, December

Weissbuch 1973-74, 'Zur Sicherheit der Bundesrepublik Deutschland und zur Entwicklung der Bundeswehr', Bonn, January

Weissbuch 1975-76, 'Zur Sicherheit der Bundesrepublik Deutschland und zur Entwicklung der Bundeswehr', Bonn, January

Weissbuch 1979, 'Zur Sicherheit der Bundesrepublik Deutschland und zur Entwicklung der Bundeswehr', Bonn, September White Paper 1983, 'The Security of the Federal Republic', Bonn, October White Paper 1985, 'The Situation and the Development of the Federal Armed Forces', Bonn, June

White Paper 1994, 'White Paper on the Security of the Federal Republic and the Situation of the Bundeswehr', Bonn, April 


\section{Press and information services of the Federal Government and ministries}

Denkschrift der Bundesregierung, 'Warum brauchen wir die Wehrpflicht?' Veröffentlich durch das Presse- und Informationsamt der Bundesregierung, April 1956

'Beteiligung der Bundeswehr an Missionen der Vereinten Nationen 1992-1994', Informationnsstab Referat Offentlichkeitsarbeit, BMVg, Bonn, February 1995

'Wehrpflicht oder Berufsarmee', Presse- und Informationsamt der Bundesregierung Referat Aussen-, Sicherheits- und Europapolitik, March 1996

Generalinspekteur der Bundeswehr zur Allgemeine Wehrpflicht, Paris, 15 May 1996, BPA Stichworte zur Sicherheitspolitik 6/96

Bundesminiterium der Verteidigung, 'Rühe zur Vorstellung des Bundeswehrplans 1997', BPA Stichworte zur Sicherheitspolitik 3/96

'Information über die Beteiligung der Bundeswehr an der stabilisierung der Friedens im ehemaligen Jugoslawien SFOR', Presse- und Informationsstab Referat Öffentlichkeitsarbeit, BMVg, Bonn, 16 December 1996

Klaus Kinkel,'Konsequenzen aus dem Urteil des Bundesverfassungsgerichts', 22 July 1994, Mitteilung für die Presses no. 1086/94, Das Auswärtige Amt

\section{Commissions}

Die Wehrstruktur in der Bundesrepublik Deutschland: Analyse und Optionen, Herausgegeben von der Wehrstruktur-Kommission im Einvernnehmen mit der Bundesregierung, Bonn, 1973 (The Force Structure in the Federal Republic of Germany: Analysis and Options, edited by the Force Structure Commission in concurrence with the Federal Government, Bonn, 1973)

Unabhängige Kommission für die künftigen Aufgaben der Bundeswehr - Absclussbericht und Empfehlungen (Bonn, 1991)

\section{Constitutional Court}

Verlautbarung der Pressestelle des Bundesverfassungsgerichts, no. 29/94, Karlsruhe, 12 July 1994: Das Urteil des Bundesverfassungsgerichts vom 12. Juli 1994, Kurzauswertung

\section{Speeches, press releases}

Embassy of the Federal Republic of Germany, 'Bundeswehr Assignments in the Context of UN Operations: Decisions of Federal Constitutional Court', Press Release 88/94, 29 July 1994 
SPD Minister of Defence Hans Apel to the 25th Commandeurtagung, Ingolstadt, Press Release, BMVg, Bonn, 27 October 1982

Generalinspekteur der Bundeswehr General Klaus Naumann, 'Sicherheitspolitik im Umbruch - Herausforderung and die Bundeswehr', Vortrag an der Führungsakademie der Bundeswehr, 19 November 1991

Generalinspekteur der Bundeswehr zur Allgemeine Wehrpflicht, 15 May 1996, BPA Stichworte zur Sicherheitspolitik, 6/96

Rede Bundesminister der Verteidigung Volker Rühe in Maßnahman zur Absicherung des Friedensvertrages für Bosnien-Herzegownia, 30 November 1995, Presse- und Informationsstab, BMVg, Bonn, 16 December 1995

Rede des Generalinspekteurs der Bundeswehr General Harald Kujat anlässlich der 39. Kommandeurtagung der Bundeswehr am 9. April 2002, Hannover, available online: www.bundeswehr.de/news/reden/reden_inspekte.../020409 _kujat_kdr_tagung. htm

\section{Ministry of Defence (BMVg)}

Bagger, Hartmut (1996) 'Allgemeine Wehrpflicht', Generalinspekteurbrief 1/96 (Bonn, 16 July)

BMVg (Fü S1 5) (ed.) (1975) Entscheidungen (11) - Auszüge aus Debatten des Deutschen Bundestages und des Bundesrates Über die Wehrverfassung und die innere Ordnung der Bundeswehr 1955-56 (Bonn)

BMVg (1982) Richtlinien zum Traditionsverständnis und zur Traditionspflege in der Bundeswehr (Bonn, September)

BMVg (1990) 'Künftige perspektiven deutscher Sicherheitspolitik', Informations zur Sicherheitspolitik (Bonn, February)

BMVg (1992) Verteidigungspolitische Rightlinien (VPR) (Bonn, 26 November)

BMVg (1994) 'Erfahrungen der Bundeswehr aus UN-Einsätzen auf dem Gebiet der Innere Führung', Zentrum Innere Führung Arbeitspapier 4/94, December

BMVg (1994) Konzeptionelle Leitlinien des Bundesministers der Verteidigung für die Weiterentwicklung der Bundeswehr (Bonn, 12 July)

BMVg (1995) Ressortkonzept zur Anpassung der Streitkräftestrukturen, der Territorialen Wehrverwaltung und der Stationierung (Bonn, 15 March)

BMVg (1996) Anpassung der Streitkräftestrukturen, der Territorialen Wehrverwaltung und der Stationierung der Bundeswehr (Bonn, 13 June)

BMVg (1996) 'Die Weiterentwicklung der Wehrpflicht' (Bonn, 15 April)

BMVg (1997) Stellungnahme des Bundesministeriums der Verteidigung zum Jahresbericht 1996 der Wehrbeauftragten des Deutschen Bundestages (Parlamentarische Staatssektretär beim, Bonn, May)

BMVg (2000) 'Gemeinsame Sicherheit und Zukunft der Bundeswehr', 23 May, available online: www.bundeswehr.de/ministerium/politik_aktuell/Bericht 
BMVg (2000) Neuaustrichtung der Bundeswehr Grobausplanung Ergebnisse und Entscheidungen (Bonn)

'Eckwerte für die Konzeptionelle and Planerische Weiterentwicklung der Bundeswehr' - 'Zussamenfassung und Schlussfolgendungen', available online: www.welt.de/go/bundeswehr/index.htx?id=162

Scharping, Rudolph (2000) Die Bundeswehr - sicher ins 21. Jahrhundert: Eckpfeiler für eine Erneuerung von Grund auf (The Bundeswehr - Advancing Steadily into the Twenty-First Century: Cornerstones of a Fundamental Renewal) (Berlin: BMVg, May)

Struck, Peter (2003) Verteidigungspolitische Richtlinien (Berlin: BMVg, 21 May)

\section{NATO}

'The Alliance's Strategic Concept', November 1991, available online: www.nato. int

London Declaration on a Transformed North Atlantic Alliance, July 1990, available online: www.nato.int

\section{Party documents}

\section{$C D U$}

CDU-Bundestageschaftsstelle, 'Deutschlands Verantwortung in der Welt', Bonn, 11 February 1991

\section{FDP}

'FDP Bundestagfraktion', Fachinfo, no. 2913, 2 July 1994

Hoyer, Werner Dr (1994) 'Bundesverfassunsgerichts-Urteil ist FDP - Erfolg auf der ganzen Linie', Frei Demokratische Korrespondenz, 12 July

Hoyer, Werner Dr, 'Soldaten brauchen Klarheit über Einsätze', Speech in the Bundestag, 22 July 1994, FDP Bundestagsfraktion Plenum Heute, no. 538

Kinkel, Klaus, 'Nicht nur Europäisch Reden, auch Handeln', Speech in the Bundestag, 30 June 1995, FDP Bundestagfraktion Dokumentation, no. 2511

'Liberale Aussenpolitik für das Vereinte Deutschland', Freie Demokratische Korrespondenz, 26 May 1991

Nolting, Günther (1994) 'SPD - Aussenpolitik führt in die Isolation', Speech in the Bundestag, 22 July, FDP Bundesfraktion Plenum Heute, no. 536

Solms, Hermann Dr (1994) 'Soldaten haben Anspruch auf Zügige Zustimmung', Speech in Bundestag, 22 July, FDP Bundestagsfraktion Plenum Heute, no. 533 


\section{CSU}

'Heimat Bayern: Zukunft Deutschland: Mit Uns', CSU Programm der Christlich-Sozialen Union der Bundestagswahl, 2 December 1990, Munich, CSU

Rühe, Volker (1991) 'Die weltpolitische Verantwortung des geeinten Deutschlands', CSU Dokumentation, no. 17

Rühe, Volker (2002) 'Zukunft der Bundeswehr - zehn Thesen', 21 March

SPD

'Bundeswehr im Ubergang', Positionspapier der Arbeitgruppe Bundeswehrstruktur, Bonn, 1990

Beschlußübersicht A1, 'Außen- Sicherheits- und Entwicklungspolitik', Presseservice der SPD, Hannover, 3 December 1997

'Social Democratic Foreign Policy in the Transition to the Twenty-First Century', Discussion Paper of the SPD Commission on Foreign and Security Policy for the Conference 18 June 1997, Bonn

'Warum die Wehrpflicht in der Bundesrepublik erhalten werden sollte!' Arbeitspapier Fraktion der SPD, Arbeitsgruppe Sicherheitsfragen, 5 September 1996

\section{Bundnis90/Die Grünen}

Joschka Fischer, 'Die Katastrophe in Bosnien und die Konsequenzen für unsere Partei Bündnis 90/Die Grünen', 30 July 1995

'Grün ist der Wechsel', Programm zur Bundestagswahl 1998, Erster Entwurf, 13 October 1997

'Auslaufsmodell Wehrpflicht: Für Entmilitarisierung, Abrüstung und Stärkung von freiwilligen Diensten', Bonn, December 1996

\section{PDS}

'Deutsche Soldaten in Alle Welt? Nein', Arbeitskreis Frieden und Antimilitarismus der PDS-Linke Liste, Landesverband, Hamburg, 1991

Glass, Michael and von Einsiedel, Heinrich Graf (1996) 'Gute Gründe für die Abschaffung der Wehrpflicht', PDS Argumentationspapier, 3 April

Hübner, Carsten (1998) 'Wehrpflicht und Bundeswehr abschaffen' in Zukunft der Wehrpflicht', Entscheidungen im neuen Bundestag Bericht der Zentralstelle KDV, November 1998 


\section{Secondary sources}

Abenheim, Donald (1988) Reforging the Iron Cross: The Search for Tradition in the West German Armed Forces (Princeton, NJ: Princeton University Press)

Abercrombie, Nicolas, Hill, Stephen and Turner, Bryan S. (1994) Dictionary of Sociology (London: Penguin)

Adenauer, Konrad (1966) Memoirs 1945-1953, trans. from the German by Henry Regnery Company, Chicago (London: Weidenfeld \& Nicolson)

Allison, G. T. (1971) Essence of Decision - Explaining the Cuban Missile Crisis (Boston, MA: Little, Brown)

Almond, G. and Verba, S. (1963) The Civic Culture (Princeton, NJ: Princeton University Press)

Anderson, Benedict (1983) Imagined Communities (London: Verso)

Baker, K., Dalton, R. and Hildebrandt, K. (1981) Germany Transformed (Cambridge, MA: Harvard University Press)

Baldwin, David (ed.) (1993) Neorealism and Neoliberalism: The Contemporary Debate (New York: Columbia University Press)

Ball, Desmond (1993) 'Strategic Culture in the Asia-Pacific Region', Security Studies, vol. 3, no. 1

Banchoff, Thomas (1997) 'The Past in the Present: Historical Memory and German National Security Policy', German Politics, vol. 6, no. 1 (April)

Baudissin, Count Wolf (1955) 'The New German Army', Foreign Affairs, vol. 34, no. 1 (October)

Von Baudissin, Wolf Graf (1977) Soldat für den Frieden (Munich: Piper)

Von Baudissin, Wolf Graf (1986) 'Dreißig Jahre Bundeswehr - Licht und Schatten', in Franz H. U. Borkenhagen (ed.) Bundeswehr Demokratie in Oliv? Streitkräfte im Wandel (Berlin and Bonn: Verlag JHW Dietz Nachf GMBH)

Baylis, John (1995) Ambiguity and Deterrence: British Nuclear Strategy 1945-1964 (Oxford: Oxford University Press)

Baylis, John and Rengger, N. J. (eds) (1992) Dilemmas in World Politics: International Issues in a Changing World (Oxford: Oxford University Press)

Berger, Thomas U. (1998) Cultures of Antimilitarism: National Security in Germany and Japan (Baltimore, MD: Johns Hopkins University Press)

Bluth, Christoph (1995) Britain, Germany and Western Nuclear Strategy (Oxford: Oxford University Press)

Booth, Ken (1979) Strategy and Ethnocentrism (New York: Holmes \& Meier)

Booth, Ken (1990) 'The Concept of Strategic Culture Affirmed', in C. G. Jacobsen (ed.) Strategic Power: USA/USSR (Basingstoke and London: Macmillan) Booth, Ken and Trood, Russell (1999) Strategic Cultures in the Asia-Pacific Region (Basingstoke: Macmillan)

Bork, Dennis L. and Gress, David R. (1989) A History of West Germany, vol. 1: From Shadow to Substance 1945-1963 (Oxford: Blackwell)

Brandt, General Jürgen (1982) 'Zur Wehrverfassung, der Bundesrepublik Deutschland Wehrpflict als Grundlage unseres Verteidigungsbeitrages', in 
Lothar Domröse (ed.) Ulrich de Maiziere, Stationen eines Soldaten lebens (Herford: Verlag E. S. Mittler \& Sohn)

Bredthauer, Karl D. (ed.) (1980) Dokumentation zur Wiederaufrüstung der Bundesrepublik (Köln: Pahl-Rugenstein Verlag)

Von Bredow, Wilfried (1969) Der Primat militärischen Denkens: Die Bundeswehr und das Problem der okkupierten öffentlichkeit (Köln: Pahl-Rugenstein Verlag)

Von Bredow, Wilfried (1992) 'Conscription, Conscientious Objection and Civic Service: The Military Institutions and Political Culture of Germany, 1945 to the Present', Journal of Political and Military Sociology, vol. 20 (winter)

Buruma, Ian (1995) Wages of Guilt: Memories of War in Germany and Japan (London: Vintage)

Buzan, Barry and Segal, Gerald (1996) 'The Rise of "Lite" Powers: A Strategy for the Postmodern State', World Policy Journal, vol. 13, no. 3 (fall)

Carlsnaes, Walter (1992) 'The Agency-Structure Problem in Foreign Policy Analysis', International Studies Quarterly, vol. 36, no. 3

Cook, Thomas I. and Moos, Malcolm (1953) 'The American Idea of International Interest' American Political Science Review, vol. 47 (March)

Craig, Gordon A. (1955) The Politics of the Prussian Army 1640-1945 (Oxford: Oxford University Press)

Dahrendorf, Ralf (1967) Society and Democracy in Germany (New York: Norton)

Van Doorn, Jacques (1975) 'The Decline of the Mass Army in the West', Armed Forces and Society, vol. 1

Duffield, John S. (1998) World Power Forsaken: Political Culture, International Institutions, and German Security Policy after Unification (Stanford, CA: Stanford University Press)

Eckstein, Harry (1988) 'A Culturalist Theory of Political Change', American Political Science Review, vol. 82, no. 3 (September)

Erb, Scott (2003) German Foreign Policy: Navigating a New Era (Boulder, CO, and London: Lynne Rienner)

Elshtain, Jean Bethke (1995) 'Feminist Themes and International Relations', in James der Derian (ed.) (1995) International Theory: Critical Investigations (London and Basingstoke: Macmillan)

Fleckenstein, B. (1988) The Military Profession in the Federal Republic of Germany (Munich: SOWI)

Fleckenstein, Bernard (1988) 'Federal Republic of Germany', in Charles C. Moskos and Frank R. Wood (eds) The Military: More than Just a Job? (Washington, DC: Pergamon-Brasseys)

Fleckenstein, Bernhard (1997) 'Warum wir die Wehrpflicht (noch) brauchen', Aus Politik und Zeitgeschichte, vol. 29

Von Friedeburg, Ludwig (1968) 'Rearmament and Social Change', in Jacques van Doorn (ed) Armed Forces and Society: Sociological Essays (The Hague and Paris: Mouton) 
Genscher, H.-D. (1990) 'Die neue europäische Friedensordnung', EuropaArchiv, no. 15

George, Alexander (1969) 'The Operational Code: A Neglected Approach to the Study of Political Leaders and Decision-Making', International Studies Quarterly, vol. 13

Gordon, Philip H. (1994) 'Normalisation of German Foreign Policy', Orbis, vol. 38 , no. 2 (spring)

Gordon, Philip H. (1995) France, Germany and the Western Alliance (Boulder, CO: Westview Press)

Gray, Colin S. (1981) 'National Style in Strategy: The American Example', International Security, vol. 6, no. 2 (fall)

Gray, Colin S. (1986) Nuclear Strategy and National Style (Lanham, MD: Hamilton Press)

Gray, Colin S. (1999) 'Strategic Culture as Context: The First Generation of Theory Strikes Back', International Affairs, vol. 25, no. 1

Green, Simon (2004) The Politics of Exclusion: Institutions and Immigration in Contemporary Germany (Manchester: Manchester University Press)

Habermas, Jürgen (1994) The Past as Future, ed. and trans. Max Pensky from the German, Vergangenheit als Zukunft: Das alte Deutschland in neuen Europa? (1994) (Cambridge: Polity Press)

Halbwachs, Maurice (1992) On Collective Memory, ed., trans. and intro. Lewis A. Coser (Chicago and London: University of Chicago Press)

Haltiner, Karl (1998) 'The Definite End of the Mass Army in Western Europe?', Armed Forces and Society, vol. 25, no. 1 (fall)

Hanrieder, Wolfram F. (1989) Germany, America, Europe: Forty Years of German Foreign Policy (New Haven, CT, and London: Yale University Press)

Harnisch, Sebastian (2004) 'Germany and Iraq', German Politics (forthcoming) Harnisch, Sebastian and Maull, Hanns W. (eds) (2000) Germany as a Civilian Power? (Manchester: Manchester University Press)

Harris, Marvin (1980) Cultural Materialism: The Struggle for a Science of Culture (New York: Vintage)

Hartrich, William (1980) Fourth and Richest Reich: How the Germans Conquered the Post War World (New York: Macmillan)

Heisbourg, Francois (2000) 'Germany's Non-Revolution in Military Affairs', Internationale Politik (Transatlantic Edition), vol. 2

Hepp, Michael and Hepp, Viktor (eds) (1996) Soldaten sind Mörder (Berlin: Christoph Links Verlag)

Herring, Eric (1995) Danger and Opportunity: Explaining International Crisis Outcomes (Manchester and New York: Manchester University Press)

Hilsman, Roger (1990) The Politics of Policy Making in Defence and Foreign Affairs, Conceptual Models and Bureaucratic Politics, 2nd edn (Englewood Cliffs, NJ, and London: Prentice-Hall)

Hoffmann, Oskar (1995) 'Innere Führung vor neuen Herausforderungen', Information für die Truppe, vol. 39, no. 1 (January) 
Hollis, Martin and Smith, Steve (1991) Explaining and Understanding International Relations (Clarendon Press: Oxford)

Holmes Cooper, Alice (1996) Paradoxes of Peace: German Peace Movements since 1945 (Ann Arbor: University of Michigan Press)

Howard, Michael (1979) 'The Forgotten Dimensions of Strategy', Foreign Affairs, vol. 57

Hundt, Ulrich A. (Flottillenadmiral) (1992) 'Nicht nur Härte bringt die Armee zum Ticken', Information für die Truppe, vol. 36, no. 11 (November)

Hyde-Price, Adrian (1996) " Of Snakes and Dragons": Contemporary German Security Policy', in Gordon Smith, William E. Paterson and Stephen Padgett (eds) Developments in German Politics, vol. 2 (Macmillan: Basingstoke)

Hyde-Price, Adrian (1999) 'Berlin Republic Takes to Arms', The World Today (June)

Hyde-Price, Adrian and Jeffery, Charlie (2001) 'Germany in the European Union', Journal of Common Market Studies, vol. 39, no. 4

IISS (1998) The Military Balance 1998-99 (New York: Oxford University Press for International Institute for Strategic Studies)

Jacobsen, Carl G. (ed.) (1990) Strategic Power: USA/USSR (Basingstoke and London: Macmillan)

Jacobsen, Hans-Adolf (1975) 'Zur Rolle der öffentlichen Meinung bei der Debatte um die Wiederbewaffnung 1950-1955', in Militärgeschichtlischen Forschungsamt (ed.) Militärgeschichte seit 1945 'Aspekte der deutschen Wiederbewaffnung bis 1955’ (Boppard am Rhein: Harald Boldt Verlag)

Jacobsen, Hans-Adolf (1995) 'Von der kollektiven Verteidigung zur kollektiven Sicherheit: Zur kontroversen sicherheitspolitischen Debatte in der Bundesrepublik Deutschland in den neunziger Jahren', in Ernst Wili Hansen, Gerhard Schreiber und Bernd Wegner (eds) Politischer Wandel, organisierte Gewalt und nationale Sicherheit (Munich: R. Oldenburg Verlag)

Jaspers, Karl (1967) The Future of Germany (Chicago, IL: University of Chicago Press)

Jervis, Robert (1976) Perception and Misperception in International Politics (Princeton, NJ: Princeton University Press)

Joffe, Josef (1996) 'German Grand Strategy after the Cold War', in Bertel Heurlin (ed.) Germany in Europe in the Nineties (London: Macmillan)

Johnston, Alistair Ian (1995) Cultural Realism: Strategic Culture and Grand Strategy in Chinese History (Princeton, NJ: Princeton University Press)

Kagan, Robert (2002) 'Power and Weakness', Policy Review, no. 113

Kaiser, Karl and Becher, Klaus (1992) 'Germany and the Iraq Conflict', in Nicole Gnesotto and John Roper (eds) Western Europe and the Gulf (Paris: Institute for Security Studies of the Western European Union)

Kaiser, Karl and Becher, Klaus (1992) 'Deutschland und der Irak-Konflikt: Internationale Sicherheitsverantwortung Deutschlands und Europas nach der deutschen Vereinigung', Arbeitspapiere zur Internationalen Politik, no. 68 (Bonn: Forschungsinstitut der DGAP) 
Katzenstein, Peter J. (ed.) (1996) The Culture of National Security Norms and Identity in World Politics (New York: Columbia University Press)

Katzenstein, Peter J. (ed.) (1997) Tamed Power: Germany in Europe (Ithaca, NY, and London: Cornell University Press)

Kelleher, Catherine M. (1990) 'Fundamentals of German Security', in Stephen F. Szabo (ed.) The Bundeswehr and Western Security (Basingstoke and London: Macmillan)

Kelleher, Catherine M. and Fisher, Cathleen (1994) 'Germany', in Douglas J. Murray and Paul R. Viotti (eds) The Defense Policies of Nations: A Comparative Study (Baltimore, MD, and London: Johns Hopkins University Press)

Keohane, Robert O; Nye, Joseph S. and Stanley Hoffman (eds) After the Cold War International Institutions and State Strategies in Europe 1989-1991 (Cambridge, MA, and London: Harvard University Press)

Kielinger, T. (1991) 'The Gulf War and the Consequences from a German Point of View', Aussenpolitik, vol. 42, no. 3

Kitchen, Martin (1975) A Military History of Germany (London: Weidenfeld \& Nicolson)

Klein, Bradley S. (1988) 'Hegemony and Strategic Culture: American Power Projection and Alliance Defence Politics', Review of International Studies, vol. 14, no. 2

Klein, Paul (1983) 'Berufs- und Zeitsoldaten in der Identifikations- und Motivationskrise', in Wolfgang R. Vogt (ed.) Sicherheitspolitik und Streitkräfte in der Legitimationskrise (Baden Baden: Nomos Verlag)

Klein, Paul and Zimmermann, Rolf P. (eds) (1997) Die zukünftige Wehrstruktur der Bundeswehr: Notwendige Anpassung oder Weg zur Zwei-KlassenArmee? (Baden-Baden: Nomos Verlagsgesellschaft)

Klein, Yitzhak (1991) 'A Theory of Strategic Culture', Comparative Strategy, vol. 10 , no. 1

Knischewski, Gerd 'Post-War National Identity in Germany', in Brian Jenkins and Spyros A. Sofos (eds) (1996) Nation and Identity in Contemporary Europe (London: Routledge)

Knoor, K. and Verba, S. (eds) (1961) The International System: Theoretical Essays (Princeton, NJ: Princeton University Press)

Köllner, Lutz, Maier, Klaus A. Meier-Dörnberg, Wilhelm and Volkmann, HansErich (1990) Anfänge westdeutscher Sicherheitspolitik 1945-1956, vol. 2: Herausgegeben vom Militärgeschichtlichen Forschungsamt (Munich: R. Oldenbourg Verlag)

Kozak, David and M. Keagle, James (eds) (1988) Bureaucratic Politics and National Security (Boulder, CO, and London: Lynne Rienner)

Kuhlmann, Jürgen (1992) 'National Service Options in Germany', SOWI Arbeitspapier, no. 67 (Munich: SOWI)

Kuhlmann, Jürgen and Lippert, Ekkehard (1994) 'Conscription on its way to National Service’, SOWI Arbeitspapier, no. 90 (Munich: SOWI) 
Kupchan, Charles A. (1994) The Vulnerability of Empire (Ithaca, NY, and London: Cornell Univerity Press)

Lapid, Yosef and Kratochwil, Friedrich (eds) (1996) The Return of Culture and Identity in IR Theory (Boulder, CO, Lynne Rienner)

Longhurst, Kerry (1998) 'German Strategic Culture: A Key to Understanding the Maintenance of Conscription in Germany', Institute for German Studies Discussion Paper Series (IGS98/6), University of Birmimgham

Longhurst, Kerry (2003) 'Why Aren't the Germans Debating the Draft?', German Politics, vol. 12, no. 2 (August)

Lord, Carnes (1985) 'American Strategic Culture', Comparative Strategy, vol. 5, no. 3

Lowry, J. Montecue (1990) The Forge of West German Rearmment (New York: Peter Lang)

Ludwigs, Michael (1995) 'Die Krisenreaktionskräfte der Bundeswehr Vorgaben für eine neue Streitkräftekategorie', Wehrtechnik, vol. 9

Lutz, Dieter S. (1997) 'Ist Eine Freiwilligen-Streitkraft billiger?', Hambuger Beiträge zur Friedensforschung und Sicherheitspolitik, no. 105 (July)

Macmillan, Alan (1995) 'Strategic Culture and National Ways in Warfare: The British Case', RUSI Journal (October)

McKenna, J. Justin (1997) 'Towards the Army of the Future: Domestic Politics and the End of Conscription in France', West European Politics, vol. 20, no. 4 (October)

Mathews, Ken (1993) The Gulf Conflict and International Relations (London: Routledge)

Maull, Hanns W. (Winter 1990-91) 'Germany and Japan: The New Civilian Powers', Foreign Affairs, vol. 69, no. 5

Maull, Hanns W. (1992) 'Zivilmacht Bundesrepublik: Vierzehn Thesen für neue deutsche Aussenpolitik', Europa-Archiv Zeitschrift für Internationale Politik, vol. 10, no. 47 (May)

Maull, Hanns W. (1993) 'Civilian Power: The Concept and its Relevance for Security Issues', in Lidija Babic and Bo Huldt (eds) Mapping the Unknown: Towards a New World Order The Yearbook of the Swedish Institute of International Affairs (Stockholm)

Maull, Hanns W. (1993) 'Zivilmacht Bundesrepublik: Das neue Deutschland in der internationalen Politik', Blätter für deutsche und Internationale Politik, no. 8

Mearsheimer, John (1990) 'Back to the Future: Instability in Europe after the Cold War', International Affairs, vol. 15, no. 1 (summer)

Meier-Dörnberg, Wilhelm (1993) 'Die Auseinandersetzung um die Einführung der Wehrpflicht in der Bundesrepublik Deutschland' (pamphlet)

Meiers, Franz-Josef (1995) 'Germany: The Reluctant Power', Survival, vol. 37, no. 3 (autumn)

Meiers, Franz-Josef (2001) 'The Reform of the Bundeswehr: Adaptation or Fundamental Renewal?', European Security, vol. 10, no. 2 (summer) 
Moskos, Charles C. and Wood, Frank R. (eds) The Military: 'More Than Just a Job?' (Washington, DC: Pergamon-Brasseys)

Naumann, Klaus (1993) 'Weder Ideologie noch Quasi-Theologie, Die neue Zdv 10/1 Innere Fuehrung', Information für die Truppe (April)

Naumann, Klaus (1994) Die Bundeswehr in einer Welt im Umbruch (Berlin: Siedler)

Noelle, Elisabeth and Neumann, Erich Peter (eds) (1967) The Germans 1947-1966 (Allensbach and Bonn: Verlag für Demoskopie)

Nolte, E. (1987 [1985]) 'Between Myth and Revisionism? The Third Reich in the Perspective of the 1980s', in Ernst Nolte and Michael Stürmer (eds) Historikerstreit (Munich: Piper)

Opel, Manfred (November 1996) 'Auslaufmodell Wehrpflichtarmee - Eckdaten zur Kontrolle einer Freiwilligenarmee’, Auslaufmodell Wehrpflichtarmee (Bremen: Zentralstelle KDV)

Van Orden, Geoffrey (1991) 'The Bundeswehr in Transition', Survival, vol. 33, no. 4 (July-August)

Parsons, Talcott (1949) 'The Problem of Controlled Institutional Change', in Essays in Sociological Theory (Glencoe, IL: Free Press)

Paterson, William E. (1974) The SPD and European Integration (Westmead: Saxon House and Lexington, MA: Lexington Books)

Pierson, Paul (1993) 'When Effect Becomes Cause: Policy Feedback and Political Change', World Politics, vol. 45, no. 4

Pöttering, Hans-Gert (1975) Adenauers Sicherheitspolitik 1955-63 (Düsseldorf: Droste Verlag $\mathrm{GmbH}$ )

Pond, Elizabeth (2004) Friendly Fire: The Near-Death of the Transatlantic Alliance (Washington, DC: EUSA-Brookings Institute Press)

Pulzer, Peter (1995) German Politics 1945-1995 (Oxford: Oxford University Press)

Pulzer, Peter (1997) Germany 1870-1945: Politics, State Formation and War (Oxford and New York: Oxford University Press)

Rautenberg, Hans-Jürgen and Wiggershaus, Norbert (1973) Himmeroder Denkschrift vom Oktober 1950: Politische und Militärische Ueberlegungen für einen Beitrag der Bundesrepublik Deutschland zur Westeuropäischen Verteidigung (Karlruhe: G. Braun)

Rengger, Nicholas J. 'Culture, Society, and Order in World Politics', in John Baylis and N. J. Rengger (eds) (1992) Dilemmas in World Politics International Issues in a Changing World (Oxford: Oxford University Press)

Ritter, Gerhard (1973) The Sword and the Scepter: The Problem of Militarism in Germany, trans Heinz Horden (Coral Gables, FL: University of Miami Press)

Rosen, Stephan Peter (1995) 'Military Effectiveness: Why Society Matters', International Security, vol. 19, no. 4

Rühe, Volker (1996) 'Growing Respnsibility', German Comments, vol. 42 (April)

Sarotte, Mary Elise (2001) German Military Reform and European Security, Adelphi Paper no. 340 (Oxford: Oxford University Press) 
Schlör, Wolfgang F. (1993) 'German Security Policy: An Examination of the Trends in German Security Policy in a New European and Global Context', in Adelphi Paper no. 277 (June) (Oxford: Oxford University Press)

Schröder, Gerhard (2001) 'Statement by the German Chancellor, Gerhard Schröder to the Germany Bundestag', 11 October 2001 in Berlin', Internationale Politik (Transatlantic Edition), vol. 2, no. 4

Schönbohm, Jörg (1996) Two Armies and One Fatherland, trans. Peter and Elfi Johnson (Oxford: Berghahn)

Schwartz, Hans-Peter (1995) Konrad Adenauer: From the German Empire to the Federal Republic 1876-1952 (Oxford: Berghahn)

Schwarz, Hans Peter (1997) Konrad Adenauer: German Politician and Statesman in a Period of War, Revolution and Reconstruction 1952-1967 (Berghahn: Oxford)

Singer, J. D. (1961) 'The Level-of-Analysis Problem in International Relations', in K. Knoor and S. Verba (eds) The International System: Theoretical Essays (Princeton, NJ: Princeton University Press)

Snyder, Jack L. (1977) The Soviet Strategic Culture: Implications for Limited Nuclear Operations, R2154-AF (Santa Monica, CA: RAND Corporation)

Sturmer, Michael (1992) Die Grenzen der Macht: Begegnung der Deutschen mit der Geschichte (Berlin: Siedler Verlag)

Swidler, A. (1986) 'Culture in Action: Symbols and Strategies', American Sociological Review, vol. 51, no. 2

Swidler, A. and Arditi, J. (1994) 'The New Sociology of Knowledge', Annual Review of Sociology

Szabo, Stephan (1990) The Changing Politics of German Security (London: Pinter)

Tanham, George (1992) 'Indian Strategic Culture', Washington Quarterly, vol. 15 , no. 1 (winter)

Twining, David T. (1989) 'Soviet Strategic Culture - the Missing Dimension', Intelligence and National Security, vol. 4, no. 1

Waltz, Kenneth (1979) Theory of International Politics (Reading, MA: AddisonWesley)

Wendt, Alexander (1992) 'Anarchy Is What States Make of It: The Social Construction of Power Politics', International Organization, vol. 46, no. 2 (spring)

Wettig, Gerhard (1967) Entmilitarisierung und Wiederbewaffnung in Deutschland 1948-1955 (Munich: R. Oldenbourg Verlag)

Wilsford, David (1994) 'Path Dependency, or Why History Makes it Difficult but Not Impossible to Reform Health Care Systems in a Big Way', Journal of Public Policy, vol. 14, no. 3

Young, Thomas-Durell (1995) 'Nationalization or Integration? The Future Direction of German Defense Policy', Defense Analysis, vol. 11, no. 2

Young, Thomas-Durrel (1996) 'German National Command Structures after Unification: A New German General Staff, Armed Forces and Society, vol. 22, no. 3 (spring) 
Zaborowski, Marcin (2005) Germany, Poland and Europe: Conflict, Cooperation and Europeanisation (Manchester: Manchester University Press)

Zaborowski, Marcin and Longhurst, Kerry (2003) 'America's Protégé in the East? The Emergence of Poland as a Regional Leader', International Affairs, vol. 79, no. 5 (October)

\section{Newspapers}

Atlantic News (1993) 'Restructuring/Military Service', no. 2498, 12 February Atlantic News (1996) 'Germany Will Keep Compulsory Military Service, Says Mr Rühe - Complimentarity Between Germany and France’, no. 2797, 6 March

BBC Monitoring International Reports - United Kingdom (2000) 'German Leaders Going for More Effective Armed Forces', 4 May

Bonner Behörden Spiegel (1997) 'Primär Bündnis-und Landesverteidigung', 1 February

Bonner Rundschau (1997) 'Armee mit Wehrpflicht unzeitgemäss', 12 August Boyes, R. (1993) 'Legal Minefield Holds Up Bonn's Combat Mission', The Times, 8 April

The Economist (2003) 'A Fractured Alliance', 15 February

The Economist (2003) 'Playing All Sides', 27 September

The Economist (2003) 'The Tune Changes - a Bit', 22 February

The Economist (2003) 'We're Not Children!' 17 May

Excite.com, 'Report Urges German Base Closings', available: http://news.excite .com/news/ap/000513/16/int-germany-military

Frankfurter Allgemeine Zeitung (1991) 'Kohl: Es darf keine Flucht aus der Verantwortung geben', 31 January

Frankfurter Allgemeine Zeitung (1994) 'Auslandseinsäize der Bundeswehr verfassungsgemäss', 13 July

Frankfurter Allgemeine Zeitung (1997) 'Verteidigung oder Krisenintervention?', 19 March

Frankfurter Rundschau (1995) 'Wir müssen für den militärischen Schutz der UN-Zonen sein', 2 August

Frankfurter Rundschau (1996 ) 'Eine Art Normalität', 14 December

Frankfurter Rundshau (2000) 'Begruendungsnotstand für die Wehrpflicht', 15 May, available online: www.fr-aktuell.de/fr/160/t160001.htm

'German Pondering a Phaseout of Conscription', online: www.iht.com:80/ IHT/TODAY/

Gillesen, G. (1991) 'Deutschland Hauptbasis für den Truppenaufmarsch am Golf', FAZ, 5 June

Handelsblatt (1997) 'Die Annäherung der Grünen an die Realität vollzieht sich im Scheckentempo', 17 November

Herald Tribune (1990) 'Bonn, in a Shift, May Send Ships to Gulf', 15 August 
Independent (1990) 'Ashamed to be in Uniform', 17 August

Internatinal Herald Tribune (1993) 'Bonn Vows to Consult NATO on Cuts', 9 February

Lamers, Karl (1991) 'Golfkrieg hat eine Katharsis im Denken bewirkt', FAZ, 2 May

Neue Zürcher Zeitung (1991) 'Kohl gegen Diskussion um eine Berufsarmee', 24 July

Neue Zürcher Zeitung (1996) 'Bonn weiterhin gegen eine Berufsarmee', 22 December

Neue Zürcher Zeitung (1996) 'Kontroverse in der FDP über eine Berufsarmee',

9 October

Newsweek (1999) 'Spoiling for a Fight', 26 April

Newsweek (1999) 'Stopping the Catastrophe', 26 April

Observer (1999) 'Kosovo - the Untold Story: How the War Was Won', Special Report, 18 July

Opel, Manfred (1997) 'Plädoyer für eine moderne und flexible Freiwilligenarmee', Frankfurter Rundschau, 20 August

Das Parlament (2000) 'Debatte um Truppenstaerke', 26 May-2 June

Rheinischer Merkur (1994) 'Besser eine Berufsarmee?', 22 April

Rose, Klaus Dr (1996) 'Eine Berufsarmee drängt zu auswärtigen Einsätzen', Frankfurter Allgemeine Zeitung, 30 July

Der Spiegel (1999) 'Alle hatten Skrupel', no. 13, 29 March

Der Spiegel (1999) 'Alle Serben im Krieg', no. 13, 29 March

Süddeutsche Zeitung (1992) 'Die Bundeswehr im Alleingang', 13 February

Süddeutsche Zeitung (1994) 'Rühe: UNO-Mandat Voraussetzung für Auslandseinsätze', 25 November

Süddeutsche Zeitung (1996) 'Eine Armee wie jede andere', 14 December

Süddeutsche Zeitung (1996) 'Liberale wollen eine Berufsarmee', 8 October

Süddeutsche Zeitung (1996) 'Wir brauchen ein milizähnliches System wie in der

Schweiz', 20 December

Süddeutsche Zeitung (1997) 'Mit Berufsarmee Aufgaben nicht zu erfüllen', 23 May

Süddeutsche Zeitung (1997) 'Rühe warnt FDP vor Irrweg bei der Wehrpflicht', 8 August

Süddeutsche Zeitung (2000) 'Umbau der Bundeswehr stoesst auf Widerstand', 8 May

Wall Street Journal (1990) 'Kohl Is Willing to Order Ships to Gulf, Signaling Readiness for New World Role', 16 August

Wall Street Journal (1991) 'Germans' Response to Gulf Underscores Nation's Search', 21 January

Washington Post (1991) 'Germany Reluctant to Defend Turkey If Iraq Retaliates', 22 January

Die Welt (1997) 'Hardthöhe verteidigt Wehrpflicht-Armee', 8 August 
Die Welt (1997) 'Schäuble: Es bleibt bei der Wehrpflicht', 9 August Die Woche (1997) 'Rettet die Wehrpflicht', 22 August Die Zeit (1990) 'Bitte kein Triumphgefühl', 5 October Die Zeit (2000) 'Die Reform-Armee - Deutschland braucht eine von Grund erneute Bundeswehr', 11 May 